\title{
PENDEKATAN RESTORATIVE JUSTICE DALAM TINDAK PELAKU PENYEBARAN HOAKS
}

\author{
Glery Lazuardi, Program Studi Magister Hukum, Program Pascasarjana \\ Universitas Jayabaya, Email: glerylazuardi@gmail.com \\ doi: https://doi.org/10.24843/KS.2020.v08.i09.p01
}

\begin{abstract}
Abstrak
Tujuan penelitian ini yakni memberikan masukan kepada aparat penegak hukum agar menggunakan pendekatan Restorative Justice terhadap pelaku penyebaran informasi tidak benar atau hoaks. Kajian ini menggunakan metode penelitian hukum normatif dengan pendekatan deskriptif analitis. Hasil dari penelitian ini menunjukkan pendekatan Restorative Justice dapat diterapkan kepada pelaku penyebaran hoaks. Sebab, penerapan Restorative Justice sudah sesuai dengan falsafah bangsa Indonesia, yaitu Pancasila khususnya sila ke-4, yang mengedepankan musyawarah. Dengan demikian, harapannya upaya pemidanaan terhadap pelaku penyebaran hoaks dapat dikurangi dan dilakukan pendekatan melalui cara mediasi antara korban dengan pelaku penyebaran hoaks.
\end{abstract}

Kata Kunci: Restorative Justice, Hoax, Penegakan Hukum dan Informasi

\begin{abstract}
The purpose of this study is to provide input to law enforcement officials using the Restorative Justice approach to the perpetrators of disseminating hoaxes. This study uses a normative legal research method with a descriptive analytical approach. The results of this study indicate that the Restorative Justice approach can be applied to the perpetrators of hoax distribution. Because, the application of Restorative Justice is in accordance with the philosophy of the Indonesian people, namely Pancasila especially the 4th precepts, which prioritizes deliberation. Thus, the hope of efforts to reduce the perpetrators of hoax distribution can be reduced and approach is carried out through mediation between the victim and the perpetrators of the spread of hoaxes.
\end{abstract}

Keywords: Restorative Justice, Hoax, Law Enforcement and Information

\section{Pendahuluan}

\subsection{Latar Belakang}

Pembicaraan mengenai hoaks bukan hal yang baru. Istilah hoaks pertama kali diperkenalkan oleh MacDouggal dalam karya klasiknya buku berjudul Hoaxes. Para peneliti telah mengakui kesulitan menentukan apa tepatnya yang memenuhi syarat sebagai hoaks MacDougall mendefinisikan hoaks sebagai "sengaja dibuat ketidakbenaran untuk menyamarkan kebenaran". Melalui definisi ini, MacDougall mencoba membedakan hoaks sebagai suatu kesalahan yang dilakukan dalam observasi atau penilaian yang membuat semua orang harus tunduk.

Seiring perkembangan zaman dan kemajuan teknologi, informasi hoaks menjadi marak beredar di masyarakat termasuk di Indonesia. Pada 2017 lalu, Masyarakat Telematika Indonesia pernah mempublikasikan hasil survei, di mana media sosial menjadi sarana yang sangat rentan dan sering digunakan sebagai tempat untuk menyebarkan berita hoaks. Sementara aplikasi obrolan daring seperti Line, Whatsapp atau Telegram menjadi saluran penyebaran hoaks yang terbanyak menurut 
$62,80 \%$ responden. Sedangkan situs web $(34,90 \%)$, televisi $(8,70 \%)$, media cetak $(5 \%)$, email $(3,10 \%)$ dan radio $(1,20 \%)$ menjadi saluran penyebaran hoaks lainnya ${ }^{1}$.

Berdasarkan hasil riset Wearesosial Hootsuite pada 2019 pengguna media sosial di Indonesia mencapai 150 juta atau sebesar 56\% dari total populasi. Jumlah tersebut naik $20 \%$ dari survei sebelumnya. Sementara pengguna media sosial mobile atau gadget mencapai 130 juta atau sekitar $48 \%$ dari populasi. Besarnya populasi, pesatnya pertumbuhan pengguna internet dan telepon merupakan potensi bagi ekonomi digital nasional ${ }^{2}$.

Satu sisi media sosial dapat meningkatkan hubungan pertemanan yang lebih erat, wadah bisnis online, dan lain sebagainya. Sisi lainnya media sosial sering menjadi pemicu beragam masalah seperti maraknya penyebaran hoaks, ujaran kebencian, hasutan, caci maki, adu domba dan lainnnya yang bisa mengakibatkan perpecahan bangsa ${ }^{3}$.

Perkembangan teknologi informasi dan komunikasi ibarat pedang bermata dua di satu sisi membawa pengaruh positif dan di sisi lain membawa pengaruh negatif. Pemanfaatan teknologi informasi dan komunikasi disatu pihak memberikan kontribusi bagi peningkatan kesejahteraan dan peradaban manusia. Sementara itu, di lain pihak kemajuan teknologi ITE tersebut dapat dimanfaatkan untuk melakukan perbuatan-perbuatan yang bersifat melawan hukum, yang menyerang berbagai kepentingan hukum orang, masyarakat dan negara 4 .

Untuk itu, diperlukan langkah antisipasi penyebaran hoaks. Berdasarkan hasil penelitian Kurniawan Hari Siswoko berjudul Kebijakan Pemerintah Menangkal Penyebaran Berita Palsu atau 'Hoax', disimpulkan pemerintah sudah melakukan pemblokiran sejumlah situs bermasalah. Kemudian, pemerintah melakukan beberapa langkah lain untuk menangkal penyebaran berita palsu. Langkah yang dimaksud adalah dengan membentuk lembaga nasional yang akan bertugas mengelola seluruh kegiatan siber yang melibatkan/membawa dampak tehadap individu, organisasi maupun perusahaan di Indonesia. Pemerintah juga menjalin kerjasama dengan Dewan Pers dan raksasa internet global, khususnya Facebook, untuk membantu menangkal penyebaran informasi hoaks ${ }^{5}$.

Selain itu, pemerintah juga sudah membuat regulasi sebagai dasar hukum penindakan kepada pelaku penyebaran hoaks. Ada beberapa peraturan yang mengatur mengenai penegakan hukum terhadap berita hoaks. Salah satu diantaranya, yaitu Undang-Undang Nomor 19 Tahun 2016 tentang Perubahan Atas UndangUndang Nomor 11 Tahun 2008 tentang Informasi dan Transaksi Elektronik. Selain itu peraturan lain dari penyebaran berita palsu atau hoaks juga bisa dijerat dengan pasalpasal lain terkait yakni pasal 310, 311, 378 dan 390 KUHP.

1 Masyarakat Telematika Indonesia: Hasil Survey Mastel Tentang Wabah Hoax Nasional. Diakses dari situs https://mastel.id/hasil-survey-wabah-hoax-nasional-2017 tanggal 5 Agustus 2020

2 We Are Social and Hootsuite: Digital IN 2019: Global Internet USE ACCELERATES. Diakses dari situs https://wearesocial.com/uk/blog/2019/01/digital-in-2019-global-internetuse-accelerates tanggal 5 Agustus 2020

3 Juditha, Christiany, Interaksi Komunikasi Hoax di Media Sosial serta Antisipasinya. Jurnal Pekommas, Vol. 3 No. 1, April 2018: hlm 33

4 Adami Chazawi dan Ardi Ferdian, Tindak Pidana Informasi dan Transaksi Elektronik. (Malang, Media Nusa Creative,2015), hlm.2.

5 Siswoko, Kurniawan Hari, Kebijakan Pemerintah Menangkal Penyebaran Berita Palsu atau 'Hoax',Jurnal Muara Universitas Tarumanegara, Vol. 1 No. 1, 2017, hlm 18 
Dengan semakin pesat perkembangan teknologi saat ini, semakin beragam dan banyak pula tindak kejahatan baru yang dilakukan lewat media elektronik, dalam kasus ini penyebaran hoaks yang sedang marak terjadi. Peraturan-peraturan yang ada saat ini terkait berita palsu telah mengatur tidak hanya pembuat berita palsu tersebut yang diberikan sanksi pidana akan tetapi juga bagi pelaku yang turut serta dalam membagikan berita bohong tersebut ${ }^{6}$.

Nyatanya angka penyebaran hoaks meningkat. Bahkan di tengah pandemi coronavirus disease 2019 (Covid-19), jumlah penyebaran hoax mengalami lonjakan. Sampai Senin (27/4/2020), Kementerian Komunikasi dan Informatika mencatat hoaks terkait pandemi Covid-19 mencapai 600. Upaya penyebaran hoaks itu dilakukan melalui berbagai macam platform digital. Sebanyak 89 tersangka kasus penyebaran hoaks telah ditindaklanjuti kepolisian. Dari jumlah tersebut, 14 orang sudah ditahan dan 75 tersangka sedang diproses hukum7 .

Sebagian besar Sistem Peradilan Pidana Indonesia selalu berakhir di penjara. Padahal penjara bukan solusi terbaik dalam menyelesaikan masalah-masalah kejahatan, khususnya tindakan kejahatan di mana kerusakan yang ditimbulkan kepada korban dan masyarakat masih bisa di restorasi sehingga kondisi yang telah rusak dapat kembali dikembalikan ke keadaan semula. Untuk itu diperlukan pendekatan mengantisipasi hoaks.

Dalam perkembangan terkini muncul sebuah alternatif yang ditawarkan yakni dengan melaksanakan konsep restorative justice. Konsep restorative justice adalah alternatif yang populer di berbagai belahan dunia untuk penanganan perbuatan melawan hukum (melawan hukum dalam arti formal) karena menawarkan solusi yang komprehensif dan efektif8.

Restorative justice tidak semata-mata menerapkan keputusan tentang siapa yang menang dan siapa yang kalah dalam sistem peradilan pidana yang bersifat permusuhan/perlawanan (adversarial system), proses restorative justice mencari suatu fasilitas dialog antara segala pihak yang terdampak oleh kejahatan termasuk korban, pelaku, para pendukungnya, dan masyarakat secara keseluruhan. Hal ini melibatkan suatu proses dimana semua pihak yang berisiko dalam kejahatan tertentu secara bersama-sama berusaha untuk menyelesaikan secara kolektif bagaimana menangani setelah terjadinya kejahatan dan implikasinya di masa depan'.

Dalam penyelesaian permasalahan bagi pelaku hoaks yang menggunakan pendekatan restorative justice ini menitikberatkan pada keadilan bagi pelaku dan korban. Dengan adanya konsep restorative justice ini dapat diketahui keadilan yang seperti apa yang tepat untuk diberikan bagi pelaku hoaks, serta pemidanaan yang akan didapat.

${ }^{6}$ Dwinanda, Renza Ardhita, Penegakan Hukum Pidana Terhadap Penyebaran Berita Bohong di Sosial Media, Journal Panorama Hukum, Vol 4 No.2, Desember 2019 hlm 122

7 Annur, Cindy Mutia:

Hoaks Seputar Covid-19 Tembus 600, Mulai dari Gibran hingga Bansos. Diakses dari situs https://katadata.co.id/berita/2020/04/27/hoaks-seputar-covid-19-tembus-600-mulaidari-gibran-hingga-bansos tanggal 24 Junil 2020

${ }^{8}$ Gordon Bazemore dan Mara Schiff, Juvenile Justice Reform and Restorative justice: Building Theory and Policy from Practice, (Oregon, Willan Publishing, 2005), hlm.5.

${ }_{9}$ Umbret Mark S. dkk, Restorative Justice in the 21st Century: A Social Movement Full of Opportunities and Pitfalls, Marquette Law Review, 2009, hlm 259-263 


\subsection{Rumusan Masalah}

Berdasarkan pemaparan yang telah diuraikan dalam latar belakang, maka penulis mengangkat permasalahan yaitu Bagaimana kajian konsep pendekatan Restorative Justice kepada pelaku penyebaran hoaks?

\subsection{Tujuan Penulisan}

Tujuan penelitian ini yakni memberikan masukan kepada aparat penegak hukum agar menggunakan pendekatan Restorative Justice terhadap pelaku penyebaran informasi tidak benar atau hoaks.

\section{Metode Penelitian}

Berdasarkan permasalahan, tulisan ini menggunakan pendekatan yuridis normatif. Yaitu menggunakan studi kasus normatif berupa produk perilaku hukum, misalnya mengkaji undang-undang. Pokok kajiannya adalah hukum yang dikonsepkan sebagai norma atau kaidah yang berlaku dalam masyarakat dan menjadi acuan perilaku setiap orang. Sehingga penelitian hukum normatif berfokus pada inventarisasi hukum positif, asas-asas dan doktrin hukum, penemuan hukum dalam perkara in concreto, sistematik hukum, taraf sinkronisasi, perbandingan hukum dan sejarah hukum ${ }^{10}$

Sedangkan dilihat dari sifatnya, penelitian ini termasuk penelitian bersifat deskriptif analitis. Yakni menggambarkan keseluruhan obyek yang akan diteliti secara sistematif dengan menganalisis data.

\section{Hasil dan Pembahasan}

\subsection{Konsep Restorative Justice}

Restorative justice adalah upaya baru melihat proses penegakan hukum pidana yang fokus mengenai bagaimana cara memperbaiki kerugian yang terjadi pada korban dan hubungan dengan pelaku pelanggar aturan. Restorative justice mulai muncul sejak tahun 1970-an berawal dari mediasi yang dilakukan antara korban dan pelaku ${ }^{11}$.

Upaya penyelesaian perkara melalui sistem peradilan yang berujung pada vonis pengadilan merupakan suatu penegakan hukum ke arah jalur lambat. Hal ini karena penegakan hukum itu melalui jarak tempuh yang panjang, melalui berbagai tingkatan mulai dari Kepolisian, Kejaksaan, Pengadilan Negeri, Pengadilan Tinggi bahkan sampai ke Mahkamah Agung. Pada akhirnya berdampak pada penumpukan perkara yang jumlahnya tidak sedikit di pengadilan ${ }^{12}$.

Untuk itu, timbul pemikiran menyelesaikan masalah hukum di luar pengadilan atau non litigasi. Restorative Justice telah menjadi perhatian pengamat dan praktisi hukum. Seorang ahli krimonologi berkebangsaan Inggris, Tony Marshall memberikan definisi Restorative Justice sebagai proses yang melibatkan semua pihak yang memiliki kepentingan dalam masalah semua pihak yang memiliki kepentingan dalam masalah pelanggaran tertentu untuk datang bersama-sama menyelesaikan secara kolektif

${ }^{10}$ Abdulkadir, Muhammad, Hukum dan Penelitian Hukum. (Bandung, PT. Citra Aditya Bakti. Cet. 1, 2004), hlm 52

${ }_{11}$ Paul Mccold dan Ted Wachtel, In Pursuit of Paradigm: A Theory of Restorative Justice, Paper ini dipresentasikan di Kongres Kriminologi Tingkat Dunia ke XIII di Rio de Janeiro, Brazil, 10-15 Agustus 2003

12 Rahardjo, Satjipto Sisi-Sisi Lain dari Hukum di Indonesia, (Jakarta, Kompas, 2003) hlm.170. 
bagaimana menyikapi dan menyelesaikan akibat dari pelanggaran dan implikasinya untuk masa depan ${ }^{13}$.

Restorative justice adalah konsep pemidanaan, tetapi sebagai konsep pemidanaan tidak hanya terbatas pada ketentuan hukum pidana (formal dan materil). Restorative Justice harus juga diamati dari segi kriminologi dan sistem pemasyarakatan ${ }^{14}$.

Menurut Bagir Manan dalam tulisannya mengemukakan tentang substansi Restorative Justice berisi prinsip-prinsip, antara lain: ${ }^{15}$

"Membangun partisipasi bersama antara pelaku, korban, dan kelompok masyarakat menyelesaikan suatu peristiwa atau tindak pidana. Menempatkan pelaku, korban, dan masyarakat sebagai stakeholders yang bekerja bersama dan langsung berusaha menemukan penyelesaian yang dipandang adil bagi semua pihak (win-win solutions)".

Penerapan Restorative Justice setidaknya harus memenuhi 3 (tiga) hal berikut ini:

1. Mengidentifikasi dan mengambil langkah-langkah untuk memperbaiki kerugian/kerusakan (identifiying and taking steps to repair harm)

2. Melibatkan semua pihak yang berkepentingan (involving all stakeholders); dan

3. Transformasi dari pola di mana negara dan masyarakat menghadapi pelaku dengan pengenaan sanksi pidana menjadi pola hubungan kooperatif antara pelaku di satu sisi dengan masyarakat/korban dalam menyelesaikan masalah akibat kejahatan (transforming the traditional relationship between communities and theirs government in responding to crime)

Stephenson, Gillet dan Brown, membedakan 4(empat) penyelesaian perkara dengan menggunakan pendekatan Restorative Justice, yaitu Victim Offender Mediation (mediasi penal), Restorative Conference (Conferencing), Family Grup Conference (FGC), dan Community Panels Meeting (CPM) ${ }^{16}$. Dalam "Explanatory Memorandum" dari Rekomendasi Dewan Eropa Nomor R (99) 19 tentang "Mediation in Penal Matters", dikemukakan 6 (enam) model mediasi penal, yaitu Informal Mediation, Traditional Village or Tribal Moots, Victim-Offender Mediation, Reparation Negotiation Programmes, Community Panels or Courts, dan Family And Community Grup Conferences ${ }^{17}$. Selain itu, juga masih banyak lagi model dan istilah yang digunakan, seperti: Circles, Restorative Board/Youth Panels, dan lain-lain.

Melihat perkembangan, Restorative Justice dapat menjadi pilihan kebijakan aparat penegak hukum. Tindak pidana hoaks sebagian besar menyerang kepentingan individu korban, sehingga, pendekatan itu dapat diterapkan. Namun, tidak semua tindak pidana hoaks dapat dilakukan Restorative Justice. Hal ini tentu saja melihat

\footnotetext{
13 Braithwaite, John, Restorative justice and Responsive Regulation. (Ofxord, Oxford University Press,2002), hlm 10

${ }^{14}$ Manan, Bagir, Resolative Justice (Suatu Perkenalan) dalam Refleksi Dinamika Hukum Rangkaian Pemikiran dalam dekade terakhir, (Jakarta, Perum Percetakan Negara RI, 2008), hlm.4.

15Ibid,hlm,.9.

16 Iswara, I Made Agus Mahendra, Mediasi Penal Penerapan Nilai-nilai Restorative Justice Dalam Penyelesaian Tindak Pidana Adat di Bali, Tesis, pada Fakultas Hukum Program Pascasarjana Universitas Indonesia, Jakarta, 2013, hlm 46-47.

17 Arief, Barda Nawawi, Sari Kuliah Hukum Pidana II. (Semarang, Fakultas Hukum Universitas Diponegoro, 1984), hlm 10
} 
seberapa besar dampak dari kerugian yang ditimbulkan korban. Upaya Restorative Justice dilakukan sebelum masuk kepada penegakan hukum. Salah satu bentuknya melalui mediasi antara korban dan pelaku. Aparat penegak hukum dapat bertindak sebagai mediator untuk menjembatani korban dan pelaku agar mencapai solusi permasalahan. Penegakan hukum melalui proses pidana dilakukan apabila tidak tercapai titik temu antara korban dan pelaku. Pada saat ini, Restorative Justice belum secara khusus diatur di ketentuan perundang-undangan. Institusi penegakan hukum, seperti Kepolisian Republik Indonesia (Polri) dan Kejaksaan Agung (Kejagung) masih menafsirkan sendiri terkait implementasi Restorative Justice.

\subsection{Mediasi Sebagai Upaya Penyelesaian Sengketa}

Mediasi penal merupakan salah satu bentuk alternatif penyelesaian sengketa di luar pengadilan atau yang biasa dikenal dengan istilah ADR atau Alternative Dispute Resolution. Mediasi merupakan salah satu bentuk penyelesaian sengketa di luar lembaga peradilan (non litigasi) dengan bantuan orang lain atau pihak ketiga yang netral dan tidak memihak serta tidak sebagai pengambil keputusan yang disebut mediator. Tujuannya di sini ialah untuk mencapai kesepakatan penyelesaian sengketa yang sedang mereka hadapi tanpa ada yang merasa dikalahkan ${ }^{18}$

ADR merupakan bagian dari Restorative Justice yang merupakan kecenderungan baru dalam upaya menyelesaikan konflik antara pelaku dan korban atau para pihak yang berselisih. Kecenderungan orang menyelesaikan konflik dengan ADR dikarenakan banyak terjadinya kasus melalui peradilan tidak mencapai sasaran dan berkeadilan. Untuk mengembangkan prinsip yang terkandung dalam penyelesaian perkara di luar pengadilan, yaitu'19:

1. Perlu Adanya Seorang Mediator Dalam Penanganan Konflik

Dalam hal ini mediator harus dapat meyakinkan mereka yang terlibat konflik dengan mengedepankan proses komunikasi. Dalam komunikasi bahwa kejahatan jika dibiarkan akan menimbulkan konflik interpersonal malahan kadang meluas menjadi konflik massa, untuk mediator harus mampu menjelaskan penting mediasi dalam rangka untuk menghilangkan rasa saki hati dan berupaya mengembalikan bahwa kejadian-kejadian tersebut merupakan kekeliruan yang harus diperbaiki dengan dasar saling pengertian.

2. Mengutamakan Kualitas Proses

Dalam melakukan mediasi yang dicari adalah kualitas proses bukan hasil untuk menentukan yang kalah dan menang, di sini dalam proses perlu adanya kesadaran dari masing-masing pihak untuk saling menghargai hingga tercapai penyelesaian win-win solution.

3. Proses Mediasi Bersifat Informal

Dalam mediasi diupayakan menghindari adanya pembicaraan yang bersifat formal, sehingga para pihak yang terlibat merasa saling dihargai.

4. Upayakan Semua Terlibat Dalam Proses Mediasi

Dalam mediasi semua harus ditanam rasa tanggungjawab tentang hasil yang akan dicapai dalam melakukan mediasi penal. Dalam pelibatan semua pihak

${ }^{18}$ I Ketut Artadi dan Dewa Nyoman Rai Asmara Putra, Pengantar Umum Tentang Alternatif Penyelesaian Sengketa dan Perancangan Kontrak, (Fakultas Hukum Universitas Udayana, Denpasar, 2009), hlm 12.

${ }^{19}$ Lasmadi, Sahuri, Mediasi Penal Dalam Sistem Peradilan Pidana Indonesia. Journal Unja 2011, hm 6 
ditanam budaya malu dan budaya saling memaafkan dengan tujuan jika proses mediasi telah berhasil semua pihak tidak merasa dipermalukan.

Upaya mediasi sesuai dengan falsafah Negara Indonesia, yaitu Pancasila. Dalam sila ke-4 Pancasila: "Kerakyatan Yang Dipimpin Oleh Hikmah Kebijaksanaan dalam Permusyawaratan/Perwakilan" terkandung falsafah permusyawaratan atau musyawarah, makna yang terkandung adalah: mengutamakan musyawarah dalam mengambil keputusan untuk kepentingan bersama, dan menghormati setiap keputusan musyawarah, keputusan yang diambil harus dapat dipertanggungjawabkan secara moral kepada Tuhan Yang Maha Esa, menjunjung tinggi harkat dan martabat manusia, nilai-nilai kebenaran dan martabat manusia, nilainilai kebenaran dan keadilan mengutamakan persatuan dan kesatuan demi kepentingan bersama-sama. Sila ke-4 Pancasila ini mengajarkan untuk menentukan sebuah pilihan melalui cara musyawarah ${ }^{20}$.

Selain itu agar dapat mengaktualisasikan Pancasila dalam politik hukum Nasional, maka sila-sila Pancasila harus dipandang sebagai suatu sistem nilai, sehingga pada hakikatnya Pancasila merupakan satu kesatuan.

Bagi bangsa dan negara Indonesia, dasar filsafat dalam kehidupan bersama itu adalah Pancasila. Pancasila sebagai core philosophy negara Indonesia, sehingga konsekuensinya merupakan esensi staatsfundamentalnorm bagi reformasi konstitusionalisme. Nilai-nilai dasar yang terkandung dalam filsafat negara tersebut, sebagai dasar filosofis-ideologis untuk mewujudkan cita-cita negara, baik dalam arti tujuan prinsip konstitusionalisme sebagai satu negara hukum formal, maupun empat cita-cita kenegaraan yang terkandung dalam Pembukaan UUD 1945, yaitu: (1) melindungi segenap bangsa dan seluruh tumpah darah Indonesia, (2) memajukan (meningkatkan) kesejahteraan umum, (3) mencerdaskan kehidupan bangsa, dan (4) ikut melaksanakan ketertiban dunia berdasarkan perdamaian abadi dan keadilan sosial 21 .

Pancasila merupakan sumber segala sumber hukum negara ${ }^{22}$. Sistem hukum nasional merupakan hukum yang berlaku di Indonesia dengan semua elemennya yang saling menunjang satu dengan yang lain dalam rangka mengantisipasi dan mengatasi permasalahan yang timbul dalam kehidupan bermasyarakat, berbangsa, dan bernegara yang berdasarkan Pancasila dan Undang-Undang Dasar Negara Republik Indonesia Tahun 1945. Undang-Undang ini merupakan penyempurnaan terhadap Undang-Undang Nomor 12 Tahun 2011 tentang Pembentukan Peraturan Perundangundangan, dan untuk memastikan keberlanjutan Pembentukan Peraturan Perundangundangan sejak perencanaan hingga Pemantauan dan Peninjauan ${ }^{23}$.

Dalam Hukum Positif Indonesia perkara pidana tidak dapat diselesaikan di luar proses pengadilan, akan tetapi dalam hal-hal tertentu dimungkinkan

20 Prayitno, Kuat Puji, Restorative Justice Untuk Peradilan di Indonesia Perspektif Yuridis Filosofis dalam Penegakan Hukum In Concreto, Jurnal Dinamika Hukum Vol. 12 No. 3 September 2012, hlm 414

${ }^{21}$ Kaelan, Peran Filsafat Bagi Pengembangan Daerah dan Peningkaan Semangat Kebangsaan, Jurnal Filsafat, Vol 17, Nomor 2, Agustus 2007, hlm 171

${ }^{22}$ Undang-Undang Nomor 12 Tahun 2011 tentang Pembentukan Peraturan PerundangUndangan yang sudah diubah menjadi Undang-Undang Nomor 15 Tahun 2019.

${ }_{23}$ Penjelasan Atas Undang-Undang Nomor 15 Tahun 2019 Tentang Perubahan Atas Undang-Undang Nomor 12 Tahun 2011 Tentang Pembentukan Peraturan PerundangUndangan 
pelaksanaanya. Dalam praktiknya penegakan hukum pidana di Indonesia, walaupun tidak ada landasan hukum formalnya perkara pidana sering diselesaikan di luar proses pengadilan melalui diskresi aparat penegak hukum, mekanisme perdamaian, lembaga adat dan sebagainya. Konsekuensi makin diterapkan eksistensi mediasi penal sebagai salah satu alternatif penyelesaian perkara di bidang hukum pidana melalui restitusi dalam proses pidana menunjukkan, bahwa perbedaan antara hukum pidana dan perdata tidak begitu besar dan perbedaan itu menjadi tidak berfungsi ${ }^{24}$.

Pada saat menyampaikan materi saat workshop di DKI Jakarta pada 18 Januari 2007 lalu, Mudzakkir mengemukakan beberapa kategori terhadap perkara yang dapat diselesaikan melalui mediasi penal adalah sebagai berikut:

1. Pelanggaran hukum pidana tersebut termasuk kategori delik aduan, baik aduan yang bersifat absolute maupun yang bersifat relatif

2. Pelanggaran hukum pidana tersebut termasuk kategori "pelanggaran", bukan "kejahatan", yang hanya diancam dengan pidana denda

3. Pelanggaran hukum pidana tersebut memiliki denda sebagai ancaman pidana dan pelanggar telah membayar denda tersebut (Pasal 80 KUHP)

4. Pelanggaran hukum pidana tersebut termasuk tindak pidana di bidang hukum administrasi yang menempatkan sanksi pidana sebagai ultimum remedium

5. Pelanggaran hukum pidana tersebut termasuk kategori ringan/serba ringan dan aparat penegak hukum menggunakan wewenangnya untuk melakukan diskresi.

6. Pelanggar hukum pidana biasa yang dihentikan atau tidak diproses ke Pengadilan oleh Jaksa Agung sesuai dengan wewenang hukum yang dimilikinya

7. Pelanggaran hukum pidana tersebut termasuk kategori pelanggaran hukum pidana adat yang diselesaikan melalui lembaga adat.

Untuk itu, upaya mediasi dapat diterapkan dalam sistem hukum Indonesia. Apabila proses mediasi tersebut berjalan dengan baik dan menghasilkan kesepakatan, maka perkara pidana tersebut selesai. Sebaliknya, jika mediasi gagal, maka proses selanjutnya adalah mengikuti proses penyelesaian perkara pidana melalui jalur litigasi. Persoalan timbul jika terjadi kesepakatan yang telah dicapai ternyata tidak dilaksanakan oleh pelaku kejahatan. Artinya, korban atau pihak yang dirugikan dapat melaporkan kepada pihak kepolisian untuk segera menangkap dan memprosesnya sebagaimana proses dalam peradilan pidana. Penyelesaian perkara pidana melalui jalur non litigasi sebagai jalur alternatif merupakan langkah yang tepat untuk mewujudkan keadilan sebagaimana diinginkan atau diharapkan masing-masing pihak $^{25}$.

\subsection{Penegakan Hukum Terhadap Penyebaran Hoaks}

Pemerintah sudah membuat dan menerapkan sejumlah aturan mengantisipasi beredarnya hoaks. Sejak 2008 lalu, Indonesia sudah mempunyai Undang-Undang Nomor 11 Tahun 2008 tentang Informasi dan Transaksi Elektronik yang sekarang telah

${ }^{24}$ Arief, Barda Nawawi, Mediasi Penal Penyelesaian Perkara Diluar Pengadilan, (Semarang, Pustaka Magister, 2008),hlm 4-5

${ }^{25}$ Raharjo, Agus, Mediasi Sebagai Basis Dalam Penyelesaian Perkara Pidana, Mimbar Hukum Volume 20, Nomor 1, Februari 2008, hlm 107 
diubah dengan lahirnya Undang-Undang No.19 tahun 2016. Selain itu, pengaturan mengenai larang hoaks diatur di Pasal 14 ayat (1) dan ayat (2) dan 15 Undang-Undang No. 1 tahun 1946 Tentang Peraturan Hukum Pidana, Pasal 311 dan 378 KUHP.

Untuk penegakan hukum, berdasarkan terbitnya Undang-Undang Nomor 19 Tahun 2016 Tentang Informasi dan Transaksi Elektronik, maka pada Pasal 27 ayat (3) juncto Pasal 45 ayat (3) UU ITE, disebutkan ancaman pidana penjara paling lama empat tahun dan/atau denda paling banyak Rp 750 juta bagi mereka yang dengan sengaja dan tanpa hak mendistribusikan dan/atau mentransmisikan dan/atau membuat dapat diaksesnya informasi elektronik dan/atau dokumen elektronik yang memiliki muatan penghinaan dan/atau pencemaran nama baik.

Pengaturan ancaman pidana juga disebutkan Pasal 28 ayat (1) juncto Pasal 45 A ayat (1), mengenai setiap orang yang dengan sengaja dan tanpa hak menyebarkan berita bohong dan menyesatkan yang mengakibatkan kerugian konsumen dalam Transaksi Elektronik sebagaimana dimaksud dalam Pasal 28 ayat (1) dipidana dengan pidana penjara paling lama 6 (enam) tahun dan/atau denda paling banyak Rp1.000.000.000,00 (satu miliar rupiah). Dan, Pasal 28 ayat (2) juncto Pasal 45 A ayat (2), disebutkan Setiap orang yang dengan sengaja dan tanpa hak menyebarkan informasi yang ditujukan untuk menimbulkan rasa kebencian atau permusuhan individu dan/atau kelompok masyarakat tertentu berdasarkan atas suku, agama, ras, dan antar golongan (SARA) sebagaimana dimaksud dalam Pasal 28 ayat (2) dipidana dengan pidana penjara paling lama 6 (enam) tahun dan/atau denda paling banyak Rp1.000.000.000,00 (satu miliar rupiah).

Selain melalui jalur hukum, upaya menyelesaikan melalui jalur mediasi terhadap pelaku hoaks dilakukan. Institusi Kepolisian Republik Indonesia (Polri) sebagai ujung tombak penegakan hukum memberi kesempatan untuk menyelesaikan perkara melalui jalur mediasi penal. Mediasi penal untuk pertama kali dikenal dalam peristilahan hukum positif di Indonesia sejak keluarnya Surat Kapolri No Pol: B/3022/XII/2009/SDEOP tanggal 14 Desember 2009 tentang Penanganan Kasus Melalui Alternative Dispute Resolution (ADR) serta Peraturan Kepala Kepolisian Negara Republik Indonesia Nomor 7 Tahun 2008 Tentang Pedoman Dasar Strategi dan Implementasi Kepolisian Masyarakat Dalam Penyelenggaraan Tugas Polri.

Disebutkan dalam Surat Kapolri tersebut beberapa langkah penanganan kasus melalui ADR, yaitu:

1. Mengupayakan penanganan kasus pidana yang mempunyai kerugian materi kecil, penyelesaiannya dapat diarahkan melalui konsep ADR.

2. Penyelesaian kasus pidana dengan menggunakan ADR harus disepakati oleh pihak-pihak yang berperkara namun apabila tidak terdapat kesepakatan baru diselesaikan sesuai dengan prosedur hukum yang berlaku secara profesional dan proporsional.

3. Penyelesaian kasus pidana yang menggunakan ADR harus berprinsip pada musyawarah mufakat dan harus diketahui oleh masyarakat sekitar dengan menyertakan RT RW setempat.

4. Penyelesaian kasus pidana dengan menggunakan ADR harus menghormati norma hukum sosial / adat serta memenuhi azas keadilan.

5. Memberdayakan anggota Pemolisian/ Perpolisian Masyarakat ("Polmas”) dan memerankan Forum Kemitraan Polisi dan Masyarakat ("FKPM") yang ada di wilayah masing-masing untuk mampu mengidentifikasi kasus-kasus pidana yang mempunyai kerugian materiil kecil dan memungkinkan untuk diselesaikan melalui konsep ADR. 
6. Untuk kasus yang telah dapat diselesaikan melalui konsep ADR agar tidak lagi di sentuh oleh tindakan hukum lain yang kontra produktif dengan tujuan Polmas.

Sementara itu, Jaksa Agung Sanitiar Burhanuddin, telah menginstruksikan kepada jajarannya mengedepankan pendekatan Restorative Justice dalam penegakan hukum. Hal ini tertuang di Peraturan Kejaksaan Republik Indonesia Nomor 15 Tahun 2020 Tentang Penghentian Penuntutan Berdasarkan Keadilan Restoratif yang diterbitkan pada 22 Juli 2020.

"Penyelesaian perkara patutnya mempertimbangkan nilai-nilai kemanusiaan. Hukum dan keadilan yang hidup di masyarakat dengan menekankan pemulihan dan keseimbangan perlindungan antar kepentingan korban dan pelaku untuk mempertegas mekanisme penyelesaian tersebut kejaksaan telah mengeluarkan kebijakan dengan mengeluarkan Peraturan Kejaksaan Nomor 15 Tahun 2020 Tentang Penghentian Penuntutan Berdasarkan Keadilan Restorative. Keadilan itu ada di hati nurani tidak ada di dalam buku. Untuk itu, setiap mengambil keputusan tanya kepada dirimu, tanya kepada hati nurani agar terjawab rasa keadilan yang diharapkan oleh masyarakat. Berkenaan dengan itu, saya yakin dan optimis melalui peningkatan kualitas yang sungguh-sungguh, pekerjaan kita adalah memberikan pelayanan publik serupa dalam menghadirkan keadilan restorative guna memulihkan kepercayaan masyarakat atau trust public dapat kita raih dan wujudkan," 26

\section{Kesimpulan}

Pendekatan Restorative Justice kepada penyebar informasi tidak benar atau hoaks relevan dilakukan. Restorative Justice dapat dilakukan dengan cara melakukan mediasi antara korban dengan pelaku penyebar hoaks. Sebagai pihak ketiga, aparat kepolisian seperti yang sudah diamanatkan di dalam Surat Kapolri No Pol: B/3022/XII/2009/SDEOP tanggal 14 Desember 2009 dapat bertindak sebagai mediator. Di sisi lain, Kejaksaan Agung sudah menerbitkan Peraturan Kejaksaan Republik Indonesia Nomor 15 Tahun 2020 Tentang Penghentian Penuntutan Berdasarkan Keadilan Restoratif yang menjadi dasar penyelesaian perkara tindak pidana dengan mengedepankan keadilan restorative. Atas dasar itu, tidak semua penyebar hoaks diproses hukum dengan cara menghadirkan ke persidangan untuk diberi hukuman yang setimpal atas apa yang diperbuat. Mengingat meskipun sudah terjadi perubahan Undang-Undang Informasi dan Transaksi Elektronik, namun upaya penyebaran hoaks masih tetap marak.

\section{Daftar Pustaka}

Buku

Adami Chazawi dan Ardi Ferdian, Tindak Pidana Informasi dan Transaksi Elektronik (Malang: Media Nusa Creative, 2015)

Bagir Manan, Resolative Justice (Suatu Perkenalan) dalam Refleksi Dinamika Hukum Rangkaian Pemikiran dalam dekade terakhir (Jakarta: Perum Percetakan Negara, 2008)

26 Pidato Jaksa Agung Sanitiar Burhanuddin di upacara peringatan Hari Bhakti Adhyaksa Tahun 2020 di aula Baharudin Lopa, Kejaksaan Agung Republik Indonesia, Rabu $(22 / 7 / 2020)$. 
Barda Nawawi Arief, Sari Kuliah Hukum Pidana II (Semarang:Fakultas Hukum Universitas Diponegoro, 1984)

Barda Nawawi Arief, Mediasi Penal Penyelesaian Perkara Diluar Pengadilan (Semarang: Pustaka Magister, 2008)

Gordon Bazemore dan Mara Schiff, Juvenile Justice Reform and Restorative justice: Building Theory and Policy from Practice (Oregon: Willan Publishing, 2005)

I Ketut Artadi dan Dewa Nyoman Rai Asmara Putra, Pengantar Umum Tentang Alternatif Penyelesaian Sengketa dan Perancangan Kontrak (Denpasar: Fakultas Hukum Universitas Udayana, 2009)

John Braitwaite, Restorative justice and Responsive Regulation (Oxford: Oxford University Press, 2002)

Muhammad Abdulkadir, Hukum dan Penelitian Hukum (Bandung: PT Citra Aditya Bakti, 2004)

Satjipto Rahardjo, Sisi-Sisi Lain dari Hukum di Indonesia (Jakarta: Kompas, 2003)

\section{Jurnal}

Dwinanda, Renza Ardhita. "Penegakan Hukum Pidana Terhadap Penyebaran Berita Bohong di Sosial Media", Journal Panorama Hukum 4, no. 2 (2019): 114-123.

Juditha, Christiany. "Interaksi Komunikasi Hoax di Media Sosial serta Antisipasinya Hoax Communication Interactivity in Social Media and Anticipation." Jurnal Pekommas 3, no. 1 (2018): 31-44.

Kaelan, Kaelan. "Peran Filsafat Bagi Pengembangan Daerah Dan Peningkatan Semangat Kebangsaan." Jurnal Filsafat 17, no. 2 (2007): 166-181.

Lasmadi, Sahuri. "Mediasi Penal Dalam Sistem Peradilan Pidana Indonesia." INOVATIF| Jurnal Ilmu Hukum 4, no. 5 (2011).

Paul Mccold dan Ted Wachtel, "In Pursuit of Paradigm: A Theory of Restorative Justice", Paper ini dipresentasikan di Kongres Kriminologi Tingkat Dunia ke XIII di Rio de Janeiro, Brazil, 2003.

Prayitno, KuatPuji. "restorative justice untuk peradilan di Indonesia (perspektif yuridis filosofis dalam penegakan hukum In concreto)." Jurnal Dinamika Hukum 12, no. 3 (2012): 407-420.

Raharjo, Agus. "Mediasi sebagai Basis dalam Penyelesaian Perkara Pidana." Mimbar Hukum-Fakultas Hukum Universitas Gadjah Mada 20, no. 1 (2008).1-19.

Siswoko, Kurniawan Hari. "Kebijakan Pemerintah Menangkal Penyebaran Berita Palsu atau 'Hoax'." Jurnal Muara Ilmu Sosial, Humaniora, dan Seni 1, no. 1 (2017): 13-19.

Umbret Mark S. dkk, "Restorative Justice in the 21st Century: A Social Movement Full of Opportunities and Pitfalls", Marquette Law Review (2009). 251-304.

\section{Peraturan Perundang-Undangan}

Undang-Undang Nomor 1 Tahun 1946 Tentang Peraturan Hukum Pidana

Undang-Undang Nomor 12 Tahun 2011 tentang Pembentukan Peraturan PerundangUndangan

Undang-Undang Nomor 19 Tahun 2016 Tentang Informasi dan Transaksi Elektronik

Undang-Undang Nomor 15 Tahun 2019 Tentang Perubahan Atas Undang-Undang Nomor 12 Tahun 2011 Tentang Pembentukan Peraturan Perundang-Undangan 


\section{Internet}

Annur, Cindy Mutia: Hoaks Seputar Covid-19 Tembus 600, Mulai dari Gibran hingga Bansos. Diakses dari situs https://katadata.co.id/berita/2020/04/27/hoaksseputar-covid-19-tembus-600-mulai-dari-gibran-hingga-bansos

Masyarakat Telematika Indonesia: Hasil Survey Mastel Tentang Wabah Hoax Nasional. Diakses dari situs https://mastel.id/hasil-survey-wabah-hoaxnasional-2017

We Are Social and Hootsuite: Digital IN 2019: Global Internet USE ACCELERATES. Diakses dari situs https://wearesocial.com/uk/blog/2019/01/digital-in-2019global-internet-use-accelerates

\section{Tesis/Disertasi}

I Made Agus Mahendra Iswara. "Mediasi Penal Penerapan Nilai-nilai Restorative Justice Dalam Penyelesaian Tindak Pidana Adat di Bali". Tesis. pada Fakultas Hukum Program Pascasarjana Universitas Indonesia, 2013: 1-249

\section{Lainnya}

Jaksa Agung ST Burhanuddin. 22 Juli 2020. Pidato di upacara peringatan Hari Bhakti Adhyaksa Tahun 2020 di aula Baharudin Lopa, Kejaksaan Agung Republik Indonesia 